\title{
Microbial abundance, composition and enzymatic activity during decomposition of copepod carcasses
}

\author{
Kam W. Tang ${ }^{1, *}$, Kristine Michelle L. Hutalle ${ }^{2}$, Hans-Peter Grossart ${ }^{2}$ \\ ${ }^{1}$ Virginia Institute of Marine Science, 1208 Greate Road, Gloucester Point, Virginia 23062, USA \\ ${ }^{2}$ Leibniz Institute of Freshwater Ecology and Inland Fisheries, Alte Fischerhuette 2, 16775 Stechlin, Germany
}

\begin{abstract}
Literature suggests that zooplankton carcasses are prevalent at times in both freshwater and marine environments, and could be important substrate sources for water column microbes (Dubovskaya et al. 2003, Hydrobiologia 504:223-227; Tang et al. 2006b, Estuar Coast Shelf Sci 68:499-508). We conducted laboratory experiments to investigate the decomposition of copepod carcasses by ambient microbes from Lake Dagow, Germany. Bacteria rapidly colonized and decomposed the carcasses, mainly from the inside. The ambient bacterial abundance increased 2 -fold or more at the peak of decomposition, but decreased afterward, presumably due to protozoan grazing. Initial increase in ambient bacteria was faster at $20^{\circ} \mathrm{C}$ than at $6^{\circ} \mathrm{C}_{i}$ however, this did not differ between aerobic and anaerobic conditions at $20^{\circ} \mathrm{C}$, suggesting that pelagic bacteria in Lake Dagow were equally adapted to both aerobic and anaerobic conditions. When bacteria were suppressed by antibiotics, the carcasses were colonized and decomposed by a massive amount of fungi; much of the fungal mass remained attached to the outside of the carcasses. DGGE analyses showed that bacterial and fungal communities of the decomposing carcasses were very different from those of natural copepod samples, indicating a shift in the microbial community at the onset of decomposition. The bacterial composition remained relatively stable, whereas the fungal composition varied greatly over time and between treatments. The ambient protease activity increased with bacterial abundance, and was at most 4 to 18 times higher than in the control (lake water). Except for the antibiotics treatment, re-suspension of carcasses in the water increased the measured protease activity by as much as 4 - to 7 -fold, indicating that protease activity was highly localized within the decomposing carcasses. Our study shows that copepod carcasses support high bacterial growth and enzymatic activities. Colonization and decomposition of the carcasses by fungi point to a previously unknown ecological role for aquatic fungi that deserves further investigation.
\end{abstract}

KEY WORDS: Detritus $\cdot$ Copepod carcasses $\cdot$ Decomposition $\cdot$ Microbial hotspots $\cdot$ Protease activity Fungi

Resale or republication not permitted without written consent of the publisher

\section{INTRODUCTION}

Detritus in aquatic environments is often characterized by high bacterial density and heterotrophic activity. Most commonly studied autochthonous detritus in aquatic environments include phytoplankton aggregates, fecal pellets and larvacean houses (Alldredge \& Silver 1988). These organic-rich detrital materials are often colonized by bacteria at densities many orders of magnitude higher than in the surrounding water (Simon et al. 2002). Elevated bacterial activities on and around the detritus could lead to its rapid remineral- ization and disintegration (Smith et al. 1992). Because rates of bacterial solubilization are often higher than those of uptake, dissolved organic matter would leak out of the detritus and benefit bacteria even in the surrounding water (Grossart \& Simon 1998, Kiørboe et al. 2001). Accumulation of bacteria due to attachment and growth would also transform the detritus into hotspots for bacterivory (Caron 1987, Kiørboe et al. 2004, Tang et al. 2006a) and genetic material exchange (Turley \& Mackie 1995).

A type of detritus less studied is carcasses of zooplankton. Zooplankton represent the most abundant 
multi-cellular organisms in the aquatic world. Not all zooplankton bodies, however, are alive in the natural environment. It is not uncommon for zooplankton to suffer mortality from starvation, diseases, pollution, injuries, environmental stresses and harmful algal blooms (Carpenter et al. 1974, Murtaugh 1981, Byron et al. 1984, Burns 1985, Ianora et al. 1987, Kimmerer \& McKinnon 1990, Hall et al. 1995, Delgado \& Alcaraz, 1999, Gomez-Gutierrez et al. 2003). Indeed, a handful of studies show that dead zooplankton are prevalent in both freshwater and marine environments (Wheeler 1967, Weikert 1977, Terazaki \& Wada 1988, Gries \& Güde 1999, Dubovskaya et al. 2003, Tang et al. 2006b). These zooplankton carcasses not only contribute to the dietary intake by deep-sea fauna (Genin et al. 1995, Haury et al. 1995), but are also important sources of organic substrates for microbes throughout the whole water column. Microbial decomposition of zooplankton carcasses provides an alternative pathway for nutrient regeneration, elemental recycling and microbial production in many aquatic ecosystems (Harding 1973, Lee \& Fisher 1992, Reinfelder et al. 1993). A recent study (Tang et al. 2006b) shows that when the carcasses of marine zooplankton were exposed to natural seawater, they were rapidly colonized and decomposed by ambient bacteria. During this process a large number of bacteria emerged from the decomposing carcasses and substantially contributed to bacterial production in the surrounding water. When bacterial activity was suppressed by the addition of antibiotics, unidentified epiphytes and protozoans were able to colonize and decompose the carcasses, but at a lower pace (Tang et al. 2006b). Although zooplankton carcasses, have been observed in both freshwater and marine environments, comparable studies on decomposition of freshwater zooplankton carcasses have not been attempted.

In the present study, we investigated the microbial decomposition of zooplankton carcasses from Lake Dagow, Germany, under different temperatures and oxygen availabilities. We measured the change in ambient bacterial abundance, composition and enzymatic activity to better characterize the decomposition process. We also studied the effects of antibiotics on the decomposition process to test whether eukaryotic microorganism such as fungi and protozoa could be of potential importance for the degradation of zooplankton carcasses.

\section{MATERIALS AND METHODS}

Study location. Lake Dagow is a eutrophic lake characterized by high plankton abundance. The bottom layer of the lake becomes hypoxic in the summer due to stratification and high organic input from the surface layer (Chan et al. 2005). The zooplankton community in the spring and summer of 2006 was dominated by the cladocerans Bosmina sp. (50\% by numerical abundance), Daphnia sp. (27\%), the cyclopoid copepods Mesocyclops leuckarti and Thermocyclops oithonoides (17\% combined) (authors' unpubl. data). In a preliminary field study, decomposing carcasses were found among the zooplankton collected from the surface layer, which clearly showed disintegration of internal tissues and high abundance of bacteria (Fig. 1). These preliminary observations confirm that zooplankton carcasses naturally occur and may serve as potential hotspots for microbial activities in Lake Dagow.

Zooplankton carcasses. Zooplankton were collected in Lake Dagow by horizontal net tow with a standard ring net $(0.5 \mathrm{~m}$ mouth diameter, $200 \mu \mathrm{m}$ mesh body, filtering cod end) just under the water surface. The cod end content was carefully transferred to a 21 container. Surface lake water was collected by submerging a 11 polycarbonate bottle. Samples were stored in a cooler and transported back to the laboratory within an hour. In the laboratory, the zooplankton sample was allowed to stand, so that dead zooplankton settled to the bottom while live zooplankton actively swam near the surface. Live zooplankton were removed from the bottle and concentrated on a nylon mesh. The live zooplank-

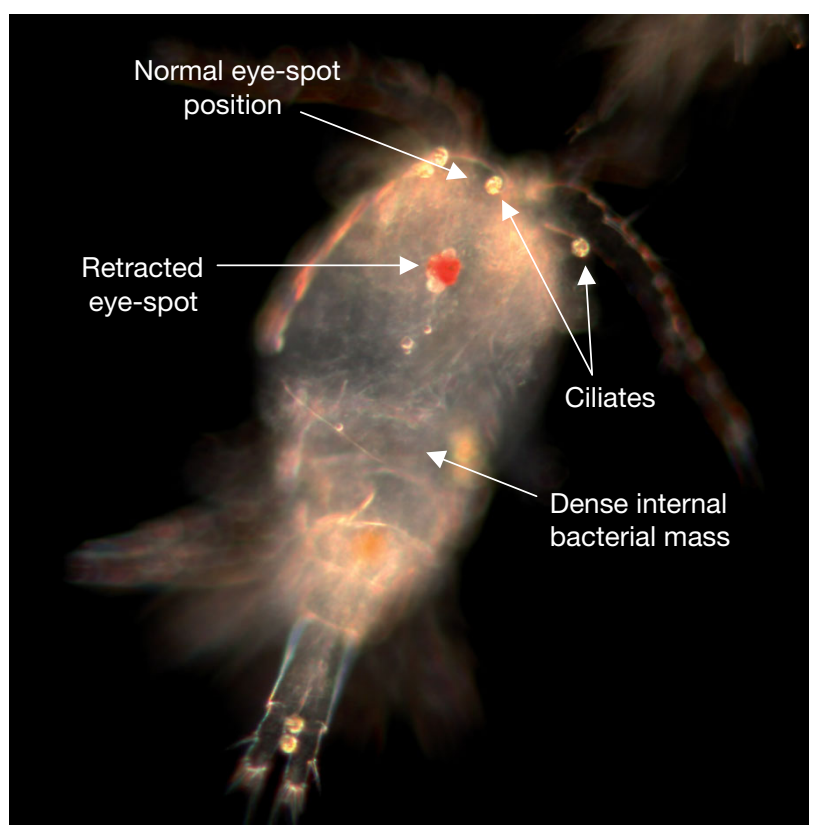

Fig. 1. Mesocyclops leuckarti. A copepod carcass (ca. $1 \mathrm{~mm}$ long) from Lake Dagow, Germany, observed with dark-field microscopy. The carcass has lost most of its internal tissues. Internal decomposition has caused the eyespot to retract from its normal position. Dense internal bacteria are clearly visible. A few ciliates can be seen on the carapace, presumably feeding on bacteria 
ton were immediately killed by brief exposure to acetic acid, rinsed repeatedly with $5 \mu \mathrm{m}$ filtered lake water and transferred to a sterile Petri dish. The carcasses were examined under a dissecting microscope, and individuals of ca. $1 \mathrm{~mm}$ in length of the copepod species Mesocyclops leuckarti and Thermocyclops oithonoides were selected for experiments. The 2 species are similar in morphology and were not separated in the present study.

Incubation experiments. Aliquots of whole and $5 \mu \mathrm{m}$ filtered lake water were taken to measure initial (Day 0) bacterial abundance and protease activity. Twenty-five fresh carcasses were preserved in a sterile $2 \mathrm{ml}$ Eppendorf vial for DGGE analysis of initial bacterial community composition associated with the copepod carcasses. The remaining copepod carcasses were randomly divided into 4 incubation series. Each series consisted of 4 Petri dishes with 50 carcasses in $20 \mathrm{ml}$ of $5 \mu \mathrm{m}$ filtered lake water under the following conditions: (1) aerobic $20^{\circ} \mathrm{C}_{i}$ (2) aerobic $6^{\circ} \mathrm{C}_{i}$ (3) anaerobic $20^{\circ} \mathrm{C}_{i}$ (4) antibiotics $20^{\circ} \mathrm{C}$. For aerobic condition the Petri dishes were loosely covered to allow gaseous exchange. For anaerobic condition the lake water was first thoroughly purged with nitrogen gas before use, and the Petri dishes were placed inside an air-tight container flushed with nitrogen gas. For the antibiotics treatment, a streptomycin/penicillin mixture (Sigma Chemicals) was added to a final concentration of $10 \mathrm{mg}$ $\mathrm{l}^{-1}$ (Tang et al. 2006b). An additional series with only $5 \mu \mathrm{m}$ filtered lake water incubated aerobically at $20^{\circ} \mathrm{C}$ was used as the control.

Microscopy. On Days 2, 4, 6 and 8, one Petri dish from each series was sacrificed for microscopy and other measurements. For ambient bacterial abundance, the contents of the Petri dish were gently mixed, and $1 \mathrm{ml}$ of the water (without carcasses or visible detritus) was withdrawn for DAPI direct counts (Porter \& Feig 1980). The aliquots were stained with $200 \mu$ of DAPI stock solution $\left(10 \mathrm{\mu g}^{-1}\right)$ and filtered onto $0.22 \mu \mathrm{m}$ black polycarbonate membranes. At least 500 to 1000 cells per sample were counted. On each of the days given above, 5 carcasses were randomly selected from each incubation series and transferred onto a glass slide. The carcasses were observed under a microscope; loss of internal tissues and appearance of dense bacterial mass were readily visible under dark-field (Tang et al. 2006b). Images of the carcasses were recorded with a digital camera (CC12, Soft Imaging System).

Microbial community composition. On each sampling day, 25 carcasses were transferred from each incubation series to a sterile $2 \mathrm{ml}$ Eppendorf vial and stored at $-20^{\circ} \mathrm{C}$ until DNA extraction. DNA of both bacteria and fungi were extracted following the protocol of Zhou et al. (1996), which includes treatment with zirconium beads and a mixture of $60^{\circ} \mathrm{C}$ hot phenol-chloro- form-isoamylalcohol. DNA extraction was checked on an agarose gel (1\%). Amplification of 16S rRNA gene fragments of bacteria using the universal primers 341fGC and 907r and subsequent DGGE analysis of bacterial community structure were performed according to Brinkhoff \& Muyzer (1997). Amplification of 18S rRNA gene fragments of fungi using the primers ITS3f-GC and ITS4r (White et al. 1990) was done according to Buscot et al. (2000). For subsequent DGGE analysis of fungal community structure the same protocol was used as for bacteria. An equal amount of DNA was loaded in each lane (ca. $500 \mathrm{ng}$ ). The denaturing gradient ranged from 40 to $70 \%$ (urea/formamide). DGGE gels were stained with SYBRGold (Molecular Probes) for 45 min and illuminated on a UV table (Biometra). Cluster analyses of the DGGE banding patterns were performed using the software GelCompare II, Version 3.5 (Applied Maths). All gels were internally standardized by selecting sequenced bands as standard. We applied 5 to $20 \%$ background subtraction depending on the signal-to-noise ratio of the corresponding gel. Patterns were compared (curve-based) by using Pearson correlation as similarity coefficient and UPGMA (unpaired group method of analysis) to generate the dendrogram. We used the curve-based approach instead of comparing single bands because this analysis is more robust (Ferrari \& Hollibaugh 1999).

Protease activity. Protease activity was measured in triplicate or quadruplicate on each sampling day using L-leucine-methyl coumarinyl amide (Leu-MCA) as a substrate analogue (Hoppe 1983). For each replicate, 5 carcasses and $3 \mathrm{ml}$ of surrounding water were transferred from each incubation series to a $1 \mathrm{~cm}$ square cuvette. Only water was used for the control series. To each cuvette, fluorogenic substrate was added to a final concentration of $0.1 \mathrm{mM}$ to ensure saturation of uptake. All cuvettes were incubated at $20^{\circ} \mathrm{C}$ in the dark for $1 \mathrm{~h}$. At the end of the incubation, the fluorescence of the cuvette was measured on a fluorometer (Kontron; excitation $365 \mathrm{~nm}$, emission $455 \mathrm{~nm}$ ). Because the carcasses settled to the bottom of the cuvette during incubation, we measured the fluorescence in 2 steps: A fluorescence reading was taken with the carcasses sitting on the bottom of the cuvette; the cuvette was then gently inverted to re-suspend the carcasses and a second fluorescence reading was taken. The first reading would represent mainly the protease activity in the ambient water; the second (higher) reading would be the result of protease activity in ambient water plus the carcasses. The ratio between the 2 readings therefore represents a conservative 'enrichment factor' for protease activity associated with the carcasses. A calibration curve for the enzyme assay was prepared by measuring the fluorescence over a range of substrate concentrations. 


\section{RESULTS}

\section{Microscopic observations}

At $20^{\circ} \mathrm{C}$ under both aerobic and anaerobic conditions the carcasses were densely colonized by bacteria after only $2 \mathrm{~d}$. During the peak of the decomposition the carcasses lost integrity and bacteria emerged from the inside (Fig. 2). Toward the end of the experiments some carcasses had lost most of the internal structures and mainly an empty carapace remained (Fig. 2). Protozoans were also seen swimming around the carcasses. The decomposition process was much slower at $6^{\circ} \mathrm{C}$, and a dense internal bacterial mass was not apparent until Day 6. In the antibiotics treatment, the carcasses remained largely intact after $4 \mathrm{~d}_{\text {i however, on Days } 6}$ and 8 the carcasses were colonized by a massive amount of epiphytic fungi (Fig. 2) and some protozoans.

\section{Bacterial abundance}

Ambient bacterial abundance in the control remained relatively constant at 4 to $5 \times 10^{6} \mathrm{cells} \mathrm{ml}^{-1}$ throughout the experiment. In contrast, bacteria surrounding the copepod carcasses increased $>2$-fold at $20^{\circ} \mathrm{C}$ in both aerobic and anaerobic treatments after $2 \mathrm{~d}$, after which it decreased rapidly to near the initial abundance (Fig. 3). At $6^{\circ} \mathrm{C}$, bacterial abundance remained low for $2 \mathrm{~d}$ but then increased after $4 \mathrm{~d}$ and remained at around $8 \times 10^{6}$ cells ml $^{-1}$ (Fig. 3). In the antibiotics treatment, bacterial abundance did not increase until Day 6 and reached a maximum of only $7 \times$ $10^{6} \mathrm{cells} \mathrm{ml}^{-1}$, after which it decreased to $3 \times 10^{6}$ cells $\mathrm{ml}^{-1}$ (Fig. 3).

\section{Microbial community composition}

DGGE banding pattern and subsequent cluster analysis revealed that bacterial community composition was variable over time and between treatments (Fig. 4A). The bacterial community of freshly killed copepods was clearly different from those incubated for 2 to $8 \mathrm{~d}$. The antibiotics treatment was very different from all other samples except for the Day $8,20^{\circ} \mathrm{C}$ aerobic sample. Surprisingly, bacterial communities on copepod carcasses of the anaerobic treatments were similar to those in the aerobic $20^{\circ} \mathrm{C}$ treatments (Days 2 to 6) indicating that fastidious anaerobes may be important for the rapid degradation of copepod carcasses at high temperatures. In contrast, bacterial composition varied little in the aerobic $6^{\circ} \mathrm{C}$ treatment (Days 4 to 8$)$, suggesting that temperature was a selecting factor for bacterial composition.
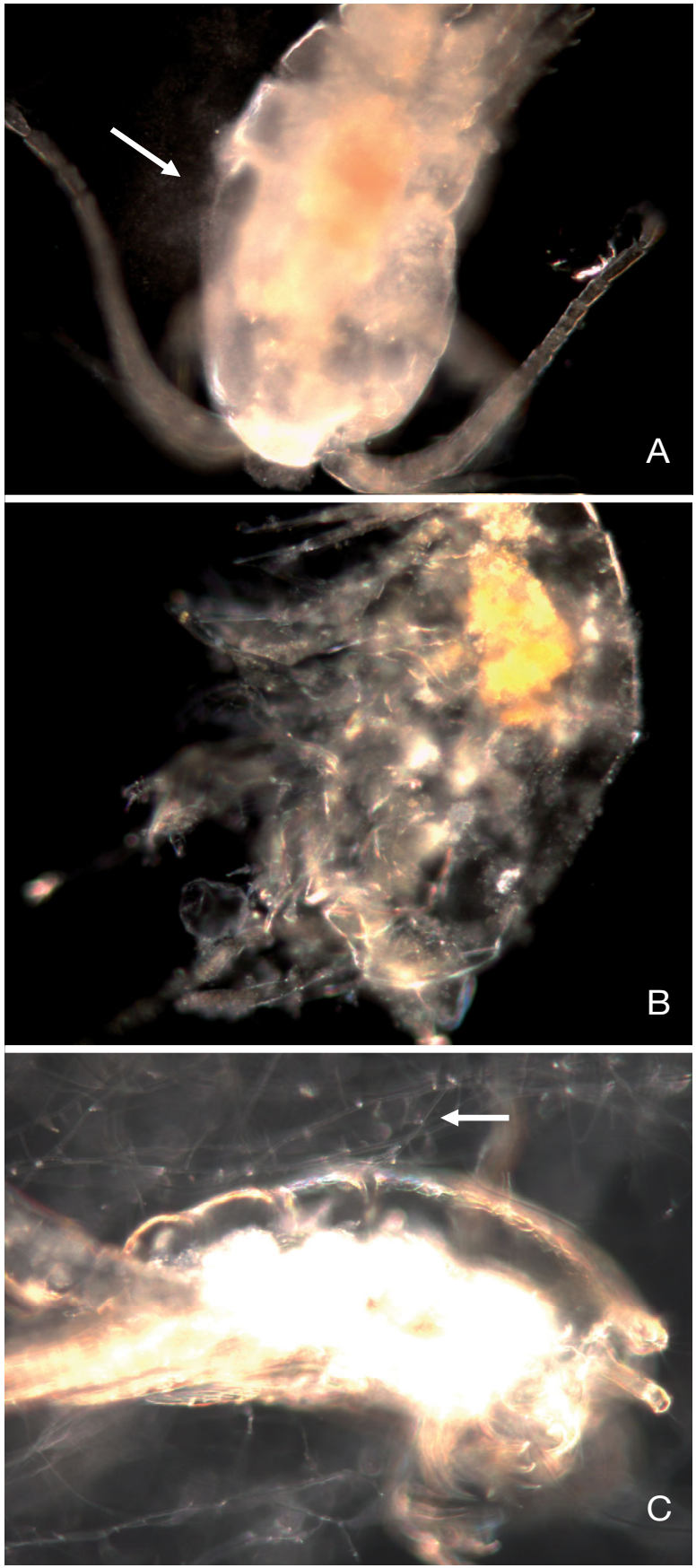

Fig. 2. (A) A copepod carcass heavily colonized by bacteria; some bacteria are emerging through fractures on the carcass (arrow). (B) A mostly empty carapace remaining at the end of decomposition. (C) In the antibiotics treatment, the carcass was colonized by a massive amount of fungi (arrow)

Fungi-specific PCR and cluster analysis of DGGE banding patterns showed that the fungal community was very diverse and varied greatly over time and between treatments (Fig. 4B). The average number of bands was much higher than that of bacteria (21 vs. 9). 


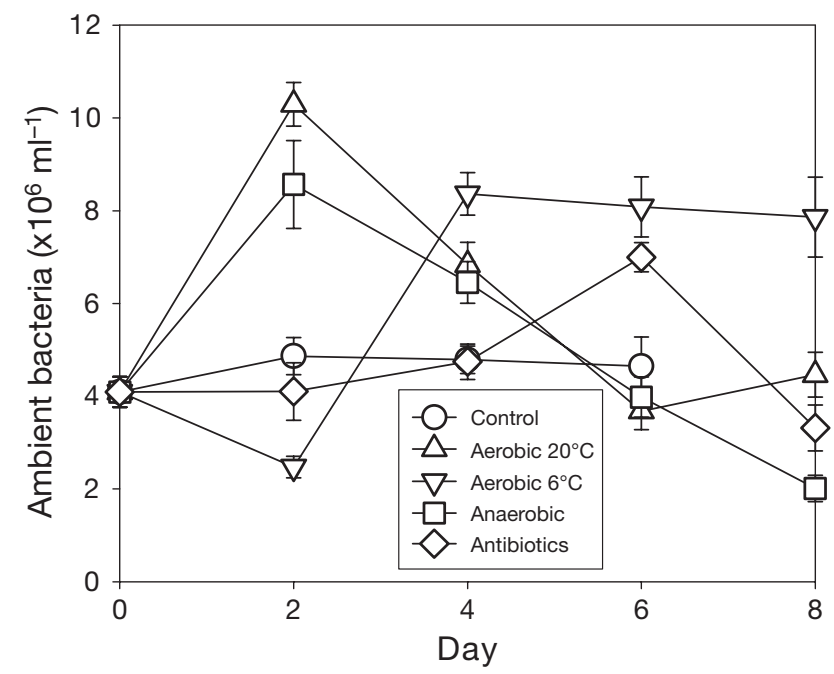

Fig. 3. Ambient bacterial abundance during decomposition of copepod carcasses under different incubation conditions. Filtered lake water without carcasses was used as a control. Bacterial count for control on Day 8 was not available. For incubation conditions, see 'Materials and methods'. Error bars represent $1 \mathrm{SD}$ of 10 replicate counts

However, cluster analysis of DGGE banding pattern did not show distinct clusters which could have been related to time or treatment, indicating that the fungal community was rather sensitive to even slight changes in environmental parameters.

\section{Protease activity}

On Day 0, there was no difference in protease activity between $5 \mu \mathrm{m}$-filtered lake water $(9.87 \pm 1.70 \mu \mathrm{M}$ $\mathrm{h}^{-1}$; mean $\left.\pm \mathrm{SD}\right)$ and unfiltered water $(11.40 \pm 1.28 \mu \mathrm{M}$ $\mathrm{h}^{-1}$; $t$-test; $\left.\mathrm{p}=0.23\right)$, indicating that most of the protease activity in suspension in Lake Dagow could be attributed to the $<5 \mu \mathrm{m}$ fraction. Protease activity associated with decomposing carcasses showed a similar temporal trend to ambient bacterial abundance, and was substantially higher than the control in most cases. At $20^{\circ} \mathrm{C}$, under both aerobic and anaerobic conditions, protease activity increased by 4 - to 6 -fold (before resuspension) after $2 \mathrm{~d}$, then gradually decreased (Fig. 5). Protease activity before re-suspension increased more slowly in the $6^{\circ} \mathrm{C}$ treatment, and was 5 times higher than the control by the end of the experiment (Fig. 5). In these 3 treatments, measured protease activity was consistently higher after re-suspension of the carcasses, suggesting that enzyme activity was highly localized within the decomposing carcasses. We calculate an enrichment factor as the ratio in measured enzyme activity after re-suspension to that before resuspension. In the present study, the enrichment factor was 4 to 7 at the peak of the decomposition process
(Fig. 6), which indicates that protease activity was at least 4 to 7 times more enriched within the decomposing carcasses relative to the surrounding water.

In the antibiotics treatment, protease activity remained relatively low in the first $4 \mathrm{~d}$, but increased $>10$-fold on Day 6, the highest among all treatments (Fig. 5). By the end of the experiment the protease activity in the antibiotics treatment remained nearly 4 times higher than in the control. However, unlike the other treatments, the enrichment factor was close to 1 on Days 6 to 8, despite the very high enzyme activity (Fig. 6), indicating that protease activity was distributed rather homogeneously in the water.

\section{DISCUSSION}

The decomposition of freshwater copepod carcasses in the present study was similar to previous observations of the marine copepod Acartia tonsa (Tang et al. $2006 b)$. In both studies, the carcasses were rapidly colonized by a dense bacterial mass, which turned the carcasses opaque under dark-field microscopy, and they gradually lost their internal tissues. At the peak of decomposition, the carcasses lost integrity and bacteria emerged from the inside, suggesting that decomposing copepod carcasses contributed new bacteria to the surrounding water. Direct evidence is provided by direct bacterial count, which showed that the ambient bacterial concentrations in all carcass treatments increased relative to the control. The rate of increase was temperature-dependent, also consistent with a previous report (Tang et al. 2006b). Contrary to our expectation, anaerobic incubation did not slow down the decomposition process, and the bacterial population dynamics were comparable to those of the aerobic treatment. Together with the high similarity in bacterial community structure between aerobic and anaerobic conditions at $20^{\circ} \mathrm{C}$, this may indicate that the pelagic bacteria in Lake Dagow are mainly fastidious anaerobes that are equally adapted to copepod carcass degradation in both aerobic and anaerobic conditions. The bacterial abundance at $20^{\circ} \mathrm{C}$ decreased quite rapidly after Day 2 , most likely due to predation by protozoans. Marine and freshwater detritus attract not only bacteria but also bacterivorous protozoans (Simon et al. 2002). In a recent mesocosm study on particle-associated bacteria, Tang et al. (2006a) showed that strong grazing pressure from bacterivorous flagellates kept the attached bacterial population at a low level. In a preliminary study, we observed ciliates swimming around decomposing copepod carcasses collected from Lake Dagow (Fig. 1), presumably feeding on the bacteria. In our laboratory experiments, we also found flagellates in the treatments, although we did not measure their abundance 


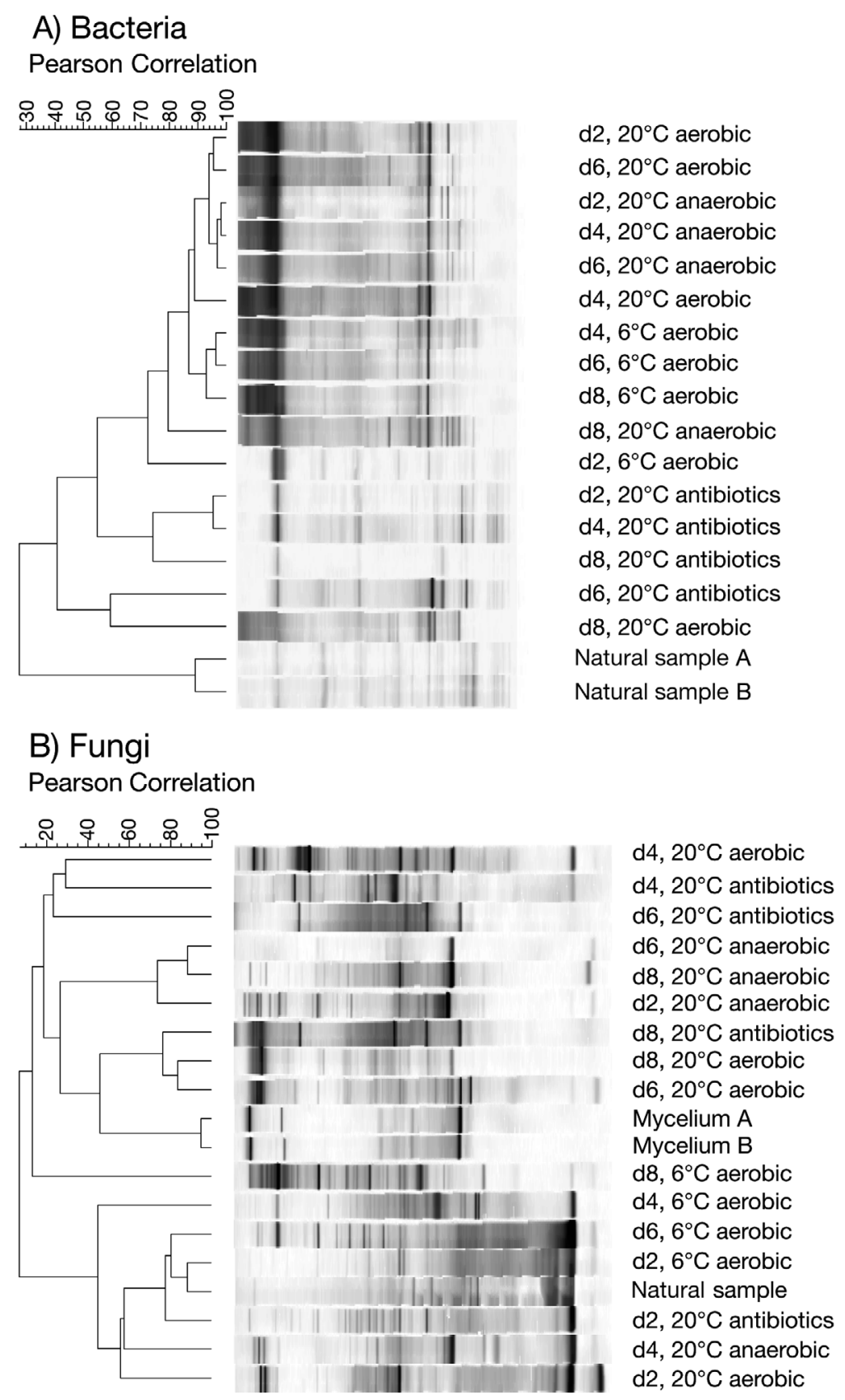

Fig. 4. Cluster analysis of DGGE banding patterns of (A) bacteria and (B) fungi over an $8 \mathrm{~d}$ incubation period. 'Natural sample' refers to freshly killed copepods with A and B being parallels. 'Mycelium' represents the fungal mycelium obtained from the antibiotics treatment on Day 8

carcasses. Whereas the bacterial compositions, with the exception of the antibiotics treatment, were relatively similar $(>70 \%)$ in most cases, the fungi were surprisingly diverse and varied greatly with time and treatment. Microscopy, however, showed that fungi reached a high abundance only when bacteria were suppressed by antibiotics. In the antibiotics treatment, fungi formed macroscopic mycelia which were visible to the naked eye (Fig. 2C). The relatively stable bacterial community composition on copepod carcasses may indicate that these bacteria were tightly regulated by substrate availability (e.g. Carlson et al. 2002, Kritzberg et al. 2006). Fungal community structure, however, seems to be more dependent on a combination of environmental factors including substrate availability, temperature and competition with bacteria (Buesing \& Gessner 2006). The high diversity of obviously different types of fungi on the freshly killed copepods compared to that of decomposing copepod carcasses indicates that even live copepods may have been naturally colonized by presumably parasitic fungi (Carman \& Dobbs 1997, Decaestecker et al. 2005).

Elevated protease activity in the treatments relative to the control indicates that bacteria and most likely fungi produced a large amount of protease to decompose the carcasses. Consistent with microscopic observations, the carcasses lost their internal tissues rapidly, whereas the chitin-based carapace was more resistant to decomposition (Tang et al. 2006b). Resuspension of the carcasses in the cuvettes led to substantially higher protease activity measurements, indicating that most of the bacterial enzyme activity was localized within the decomposing carcasses, which was also consistent with the microscopic observation of dense bacterial mass inside the carcasses at the peak of decomposition. Other researchers

or grazing rate. Interestingly, the bacterial abundance did not decrease in a similar fashion at $6^{\circ} \mathrm{C}$. This observation suggests that protozoan activity was reduced by the low temperature more so than the bacteria, which allowed the bacteria to maintain a high abundance toward the end of the experiment.

Abundance and DGGE banding patterns of bacteria and fungi revealed that both rapidly colonize copepod have also reported elevated enzymatic activities associated with marine and freshwater particles (Karner \& Herndl 1992, Riemann et al. 2000, Karrasch et al. 2004), which may result in rapid hydrolysis of the particles and subsequent leaching of dissolved organic materials from the particles (Smith et al. 1992, Grossart \& Simon 1998, Kiørboe et al. 2001). In our experiments, a decomposing carcass supported protease activity up 


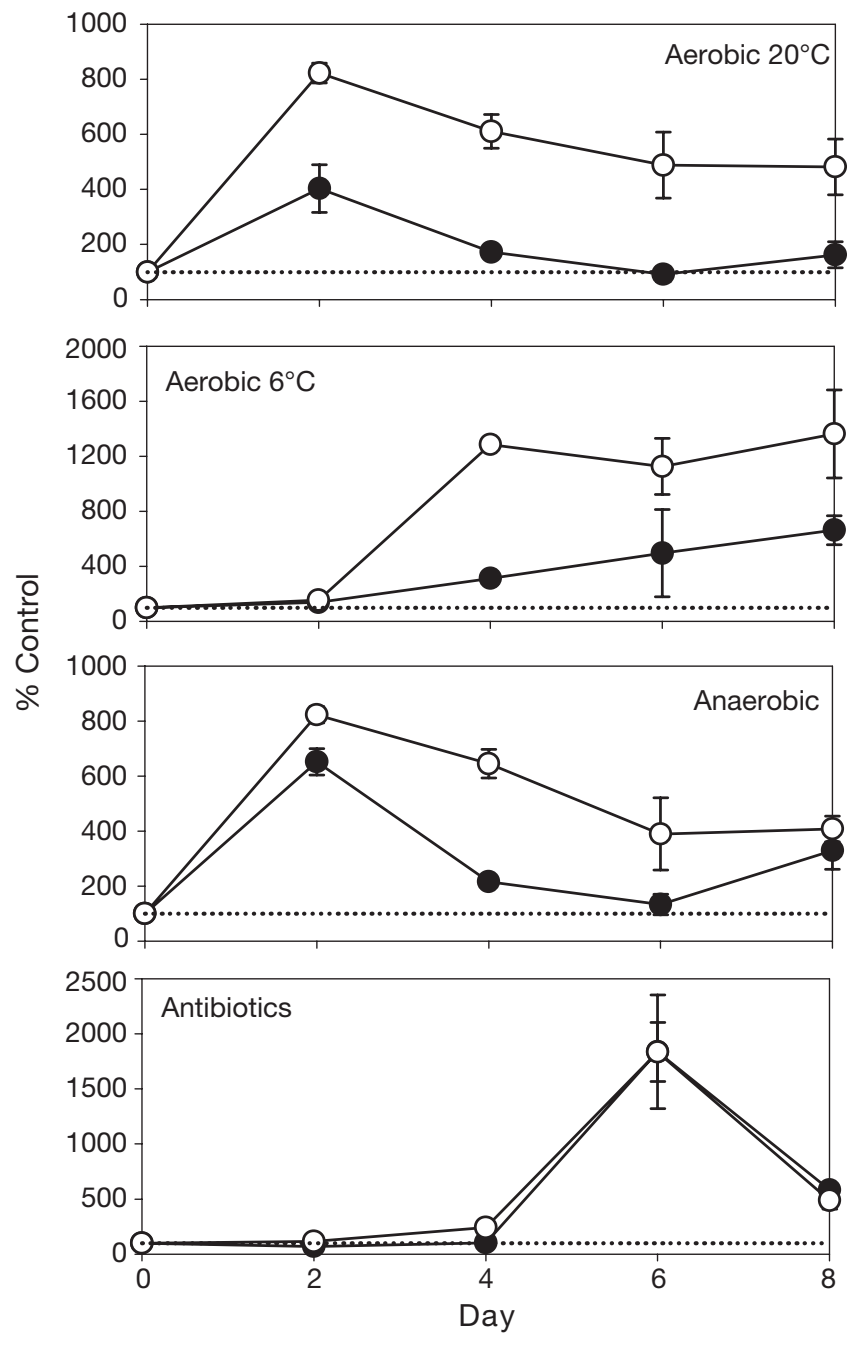

Fig. 5. Protease activity measured before $(\bullet)$ and after (O) resuspension of carcasses from different treatments (mean \pm $\mathrm{SD} ; \mathrm{n}=3$ to 4 ). Activities are expressed as percent control. Dotted line represents $100 \%$

to 7 times higher than in the surrounding water. These observations support the notion that detrital particles in aquatic environments are hotspots where intense microbial activities occur on a microscopic spatial scale. Conventional sampling of bulk water properties would therefore underestimate microbial activities associated with these hotspots.

Interestingly, the maximum protease activity in the antibiotics treatment was the highest among all treatments, although the corresponding ambient bacterial abundance was not. Microscopic observations showed that these carcasses were heavily colonized by epiphytic fungi, which might contribute to the high protease activity. Fungi play a key role in decomposing leaf litters and other allochthonous detritus in freshwater ecosystems (e.g. Buesing \& Gessner 2006), and fungal infection of copepods and their eggs in

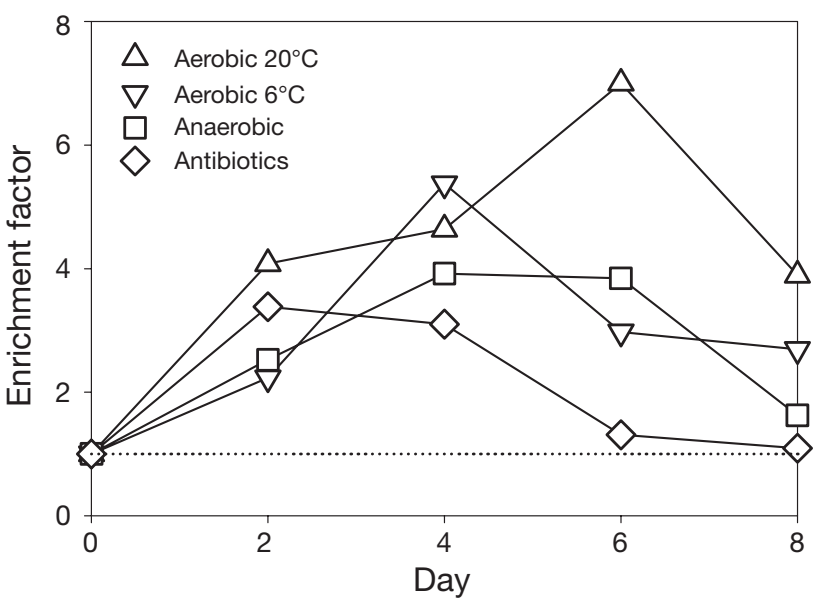

Fig. 6. Conservative estimates of enrichment factor for protease activity associated with decomposing copepod carcasses relative to the surrounding water. Dotted line represents a factor of 1

eutrophic lakes has been frequently observed (Redfield \& Vincent 1979, Burns 1980, 1985), but their role in decomposing plankton carcasses has to date not been reported. In a study with the marine copepod Acartia tonsa, Tang et al. (2006b) also observed that copepod carcasses were decomposed by unidentified epiphytes in the presence of antibiotics. Their work and the present study show that fungi in aquatic environments are able to decompose plankton carcasses, although they tend to be out-competed by bacteria. Another interesting observation is that the enrichment factor in the antibiotics treatment remained close to 1 despite the very high protease activity on Days 6 to 8 , when the carcasses were entangled in a massive meshwork of fungi. Unlike the bacteria, which colonized and multiplied inside the carcasses, much of the fungal mass remained on the outside of the carcasses. As a result, ectoenzymes released by the fungi would more readily diffuse into the surrounding water, which would contribute to protease activity in the ambient water and an enrichment factor close to 1 . These results show that bacteria and fungi rapidly decompose detrital materials and contribute to ambient enzymatic activity in very different ways.

Traditional field sampling of zooplankton tends to ignore its living or dead status. Yet non-consumptive mortality (mortality not due to predation) could be high at times (Gries \& Güde 1999, Dubovskaya et al. 2003, Tang et al. 2006b). Without distinguishing between living and dead zooplankton one not only overestimates the viable zooplankton population but also underestimates their contribution to microbial production in the water column. Although zooplankton carcasses probably contribute only a minor fraction of bacteria to the total water column bacterial population (Tang et al. 
2006b), they are nonetheless microbial hotspots where microbial activities proceed at high rates relative to the ambient water. Our recent study suggests that individual isolates of marine snow bacteria can rapidly regulate their protease activity upwards and downwards while on and off aggregate surfaces (Grossart et al. 2007). This ability allows the bacteria to conserve energy when in suspension, but rapidly exploit aggregate resources upon attachment and attain high growth. Similarly, for a bacterium, zooplankton carcasses represent highly concentrated substrate sources in an otherwise nutritionally dilute environment; being able to exploit these resources will be crucial to the survival and proliferation of the bacterium.

\section{CONCLUSIONS}

Our results show that decomposing zooplankton carcasses support high bacterial activities and a rather uniform bacterial community. For the first time we report on the ability of fungi to decompose zooplankton carcasses and contribute to ambient protease activity. These observations suggest a previously unknown ecological role of aquatic fungi that deserves further investigation.

Acknowledgements. This study was supported by US NSF OCE-0352125 (K.W.T.) and by the Leibniz foundation. We thank Dr. P. Kasprzak and A. Scheffler for zooplankton species identification, S. Boekhoff for fungal DGGE analysis and E. Mach for technical assistance. Contribution no. 2789 of Virginia Institute of Marine Science.

\section{LITERATURE CITED}

Alldredge AL, Silver M (1988) Characteristics, dynamics and significance of marine snow. Prog Oceanogr 20:41-58

Brinkhoff T, Muyzer G (1997) Increased species diversity and extended habitat range of sulfur-oxidizing Thiomicrospira spp. Appl Environ Microbiol 63:3789-3796

Buesing N, Gessner MO (2006) Benthic bacterial and fungal productivity and carbon turnover in a freshwater marsh. Appl Environ Microbiol 72:596-605

Burns CW (1980) Occurrence of Aphanomyces ovidestruens, a fungus parasitic on copepods, in two eutrophic lakes. NZ J Mar Freshw Res 14:23-29

Burns CW (1985) Fungal parasitism in a copepod population: the effects of Aphanomyces on the population dynamics of Boeckella dilatata Sars. J Plankton Res 7:201-205

Buscot F, Munch JC, Charcosset JY, Gardes M, Nehls U, Hampp R (2000) Recent advances in exploring physiology and biodiversity of ectomycorrhizas highlight the functioning of these symbioses in ecosystems. FEMS Microbiol Rev 24:601-614

Byron ER, Folt CL, Goldman CR (1984) Copepod and cladoceran success in an oligotrophic lake. J Plankton Res 6: $45-65$

Carlson CA, Giovannoni SJ, Hansell DA, Goldberg SJ, Parsons R, Otero MP, Vergin K, Wheeler BR (2002) Effect of nutrient amendments on bacterioplankton production, community structure, and DOC utilization in the northwestern Sargasso Sea. Aquat Microb Ecol 30:19-36

Carman KR, Dobbs FC (1997) Epibiotic microorganisms on copepods and other marine crustaceans. Microsc Res Tech 37:116-135

Caron DA (1987) Grazing of attached bacteria by heterotrophic microflagellates. Microb Ecol 13:203-218

Carpenter EJ, Peck BB, Anderson SJ (1974) Survival of copepods passing through a nuclear power station on northeastern Long Island Sound, SA. Mar Biol 24:49-55

Chan OC, Claus P, Casper P, Ulrich A, Lueders T, Conrad R (2005) Vertical distribution of structure and function of the methanogenic archaeal community in Lake Dagow sediment. Environ Microbiol 7:1139-1149

Decaestecker E, Declerck S, De Meester L, Ebert D (2005) Ecological implications of parasites in natural Daphnia populations. Oecologia 144:382-390

Delgado M, Alcaraz M (1999) Interactions between red tide microalgae and herbivorous zooplankton: the noxious effects of Gyrodinium corsicum (dinophyceae) on Acartia grani (Copepoda: Calanoida). J Plankton Res 21: 2361-2371

Dubovskaya O, Gladyshev M, Gubanov VG, Makhutova ON (2003) Study of non-consumptive mortality of crustacean zooplankton in a Siberian reservoir using staining for live/dead sorting and sediment traps. Hydrobiologia 504: 223-227

Ferrari VC, Hollibaugh JT (1999) Distribution of microbial assemblages in the central Arctic Ocean basin studied by PCR/DGGE: analysis of a large data set. Hydrobiologia 401:55-68

Genin A, Gal G, Haury L (1995) Copepod carcasses in the ocean. II. Near coral reefs. Mar Ecol Prog Ser 123:65-71

Gomez-Gutierrez J, Peterson WT, De Robertis A, Brodeur RD (2003) Mass mortality of krill caused by parasitoid ciliates. Science 301:339

Gries T, Güde H (1999) Estimates of the nonconsumptive mortality of mesozooplankton by measurement of sedimentation losses. Limnol Oceanogr 44:459-465

Grossart HP, Simon M (1998) Bacterial colonization and microbial decomposition of limnetic organic aggregates (lake snow). Aquat Microb Ecol 15:127-140

Grossart HP, Tang KW, Kiørboe T, Ploug H (2007) Comparison of cell-specific activity between free-living and attached bacteria using isolates and natural assemblages. FEMS Microbiol Lett 266:194-200

Hall LW Jr, Ziegenfuss MC, Anderson RD, Killen WD Jr (1995) Use of estuarine water column tests for detecting toxic conditions in ambient areas of the Chesapeake Bay watershed. Environ Toxicol Chem 14:267-278

Harding GCH (1973) Decomposition of marine copepods. Limnol Oceanogr 18:670-673

Haury L, Fey C, Gal G, Hobday A, Genin A (1995) Copepod carcasses in the ocean. I. Over seamounts. Mar Ecol Prog Ser 123:57-63

Hoppe HG (1983) Significance of exoenzymatic activities in the ecology of brakish water: measurements by means of methylumbelliferyl-substrates. Mar Ecol Prog Ser 11: 299-308

Ianora A, Mazzocchi MG, Scotto di Carlo B (1987) Impact of parasitism and intersexuality on Mediterranean populations of Paracalanus parvus (Copepoda: Calanoida). Dis Aquat Org 3:29-36

Karner M, Herndl G (1992) Extracellular enzymatic activity and secondary production in free-living and marinesnow-associated bacteria. Mar Biol 113:341-347 
Karrasch B, Ullrich S, Mehrens M, Zimmermann-Timm H (2004) Free and particle-associated extracellular enzyme activity and bacterial production in the lower Elbe estuary, Germany. Acta Hydrochim Hydrobiol 31:297-306

Kimmerer WJ, McKinnon AD (1990) High mortality in a copepod population caused by a parasitic dinoflagellate. Mar Biol 107:449-452

Kiørboe T, Ploug H, Thygesen UH (2001) Fluid motion and solute distribution around sinking aggregates. I. Smallscale fluxes and heterogeneity of nutrients in the pelagic environment. Mar Ecol Prog Ser 211:1-13

Kiørboe T, Grossart HP, Ploug H, Tang K, Auer B (2004) Particle-associated flagellates: swimming patterns, colonization rates, and grazing on attached bacteria. Aquat Microb Ecol 35:141-152

Kritzberg ES, Langenhede S, Lindström E (2006) Influence of dissolved organic matter source on lake bacterioplankton structure and function-implications for seasonal dynamics of community composition. FEMS Microbiol 56:406-417

Lee BG, Fisher NS (1992) Decomposition and release of elements from zooplankton debris. Mar Ecol Prog Ser 88: 117-128

Murtaugh PA (1981) Inferring properties of mysid predation from injuries to Daphnia. Limnol Oceanogr 26:811-821

Porter KG, Feig YS (1980) The use of DAPI for identification and enumeration of bacteria and blue-green algae. Limnol Oceanogr 13: 389-398

Redfield GW, Vincent WF (1979) Stages of infection and ecological effects of a fungal epidemic on the eggs of a limnetic copepod. Freshw Biol 9:503-510

Reinfelder JR, Fisher NS, Fowler SW, Teyssié JL (1993) Release rates of trace elements and protein from decomposition of plankton debris. 2. Copepod carcasses and sediment trap particulate matter. J Mar Res 51:423-442

Riemann L, Steward GF, Azam F (2000) Dynamics of bacteria

Editorial responsibility: Paul del Giorgio,

Montréal, Québec, Canada community composition and activity during a mesocosm diatom bloom. Appl Environ Microbiol 66:578-587

Simon M, Grossart HP, Schweitzer B, Ploug H (2002) Microbial ecology of organic aggregates in aquatic ecosystems. Aquat Microb Ecol 28:175-211

Smith DC, Simon M, Alldredge AL, Azam F (1992) Intense hydrolytic enzyme activity on marine aggregates and implications for rapid particle dissolution. Nature 359: 139-142

Tang KW, Grossart HP, Yam EM, Jackson GA, Ducklow HW, Kiørboe T (2006a) Mesocosm study of particle dynamics and control of particle-associated bacteria by flagellate grazing. Mar Ecol Prog Ser 325:15-27

Tang KW, Freund CS, Schweitzer CL (2006b) Occurrence of copepod carcasses in the lower Chesapeake Bay and their decomposition by ambient microbes. Estuar Coast Shelf Sci 68:499-508

Terazaki M, Wada M (1988) Occurrence of large numbers of carcasses of the large, grazing copepod Calanus cristatus from the Japan Sea. Mar Biol 97:177-183

Turley CM, Mackie PJ (1995) Bacterial and cyanobacterial flux to the deep NE Atlantic on sedimenting particles. Deep-Sea Res I 42:1453-1474

Weikert H (1977) Copepod carcasses in the upwelling region south of Cape Blanc, NW Africa. Mar Biol 42:351-355

Wheeler EH (1967) Copepod detritus in the deep sea. Limnol Oceanogr 12:697-701

White TJ, Bruns T, Lee S, Taylor J (1990) Amplification and direct sequencing of fungal ribosomal RNA genes for phylogenetics. In: Innis MA, Gelfand DH, Sninsky JJ, White TJ (eds) PCR protocols, a guide to methods and applications. Academic Press, San Diego, CA, p 315-322

Zhou J, Bruns MA, Tiedje JM (1996) DNA recovery from soils of diverse composition. Appl Environ Microbiol 62: $695-724$

Submitted: July 24, 2006; Accepted: November 15, 2006 Proofs received from author(s): December 17, 2006 